Бычков С. А., Донеи А. Д., Шмырев В. Ф.

Государственное предприятие «АНТОНОВ». Украина, г. Киев

\title{
РАЗРАБОТКА КОНЦЕПЦИИ ОТЕЧЕСТВЕННОГО СРЕДНЕГО ВОЕННО-ТРАНСПОРТНОГО САМОЛЕТА С ТУРБОРЕАКТИВНЫМИ ДВУХКОНТУРНЫМИ ДВИГАТЕЛЯМИ
}

Рассмотрены особенности конструктивных и технологических изменений отечественного военно-транспортного самолета (ВТС), связанных с установкой турбореактивных двухконтурных двигателей (ТРДД) СFM Lеар вместо турбовинтовентиляторных двигателей (ТВВД).

Отмечены и квалифицированы изменения, связанные с улучшением самолета по результатам наземных и летных испытаний, учетом стандартов НАТО, касающихся конструкции планера и систем самолета.

Рассмотрены технологические аспекты организации производства отечественного военнотранспортного самолета с ТРДД.

Создание отечественного среднего военно-транспортного самолета (Ан-188) с ТРДД производится с максимальным использованием научно-технического задела, наработанного при создании отечественного среднего военно-транспортного самолета с ТВВД с сохранением основных конструктивных, аэродинамических и прочностных характеристик с учетом выполнения требований летной годности EASA CS-25, MIL-STD, STANAG. [dx.doi.org/10.29010/89.1]

Ключевые слова: кониепиия; средний оперативно-тактический военно-транспортный самолет; турбореактивный двихконтурный двигатель; турбовинтовентиляторный двигатель; конструкиия планера и систем самолета; конструктивных, аэродинамических и прочностных характеристик; требования летной годности.

Введение

С принятием на вооружение А400M, C-2 и Ан-70 в мире начал формироваться новый сегмент рынка - оперативно-тактические ВТС (рис. 1). Успешность развития сегмента и его влияние на конъюнктуру спроса определится уровнем технического совершенства самолетов и результатами применения вооруженными силами.

В отличие от средних ВТС предыдущих поколений, современные средние ВТС, располагая возможностью перевозки до 98\% номенклатуры воен-

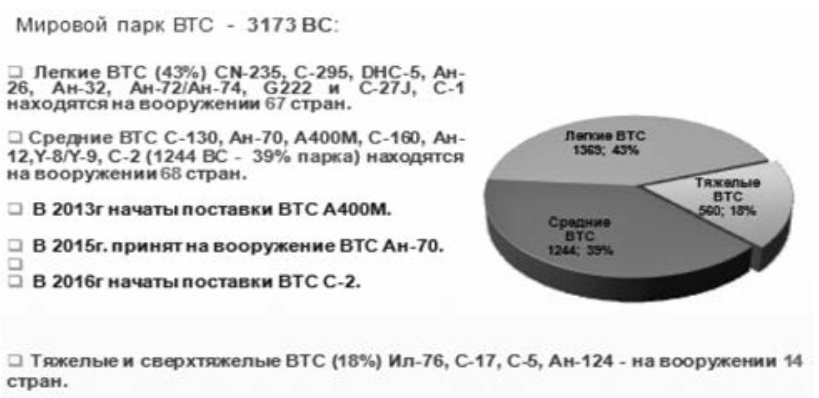

a) ной техники, включая бронированную, обеспечивают вооруженным силам стран мира новое определяющее функциональное качество - аэромобильность войск современного уровня оснащения и позволяют достигать с высокой эффективностью преимущества над противником в решении тактических и оперативно-тактических задач.

Как правило, военно-транспортные самолеты используются для следующих целей:

1. Перевозка войск, парашютистов.

2. Перевозка оружия.

3. Перевозка другого военного оборудования.

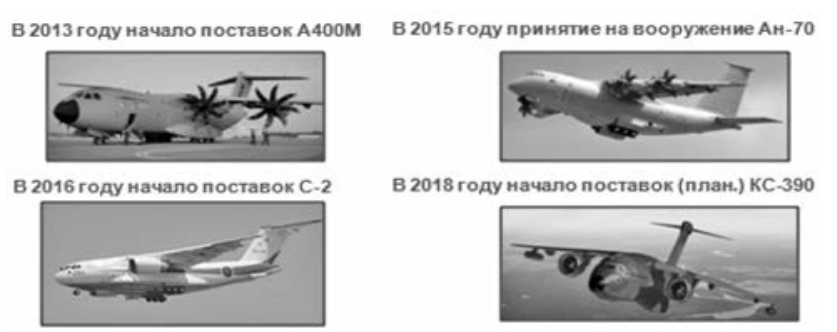

б)

Рис. 1. Новый сегмент рынка - оперативно-тактические ВТС: a) современная структура мирового парка ВТС; б) изменение условий конкуренции после 2013 года 
4. Разведка и наблюдение.

5. Медицинская эвакуация и гуманитарная поддержка.

6. Дозаправка в воздухе/самолеты-заправщики.

7. Спасательные операции.

8. Перевозка оперативно-тактичных и стратегических грузов.

\section{1. Отечественный средний \\ оперативно-тактический военно-транспортный самолет с ТВВД (табл. 1)}

Таблица 1

Основные летно-технические характеристики отечественного среднего оперативнотактического военно-транспортного самолета с ТВД (рис. 2)

\begin{tabular}{|l|c|c|}
\hline \multicolumn{1}{|c|}{ Режим применения } & $\begin{array}{c}\text { Режим } \\
\text { ОВП }\end{array}$ & $\begin{array}{c}\text { Режим } \\
\text { КВП }\end{array}$ \\
\hline Потребная длина ВПП, м & 1900 & $600-700$ \\
\hline Взлетная масса, т & 145 & 118 \\
\hline Грузоподъемность, т: & 47 & - \\
- перегрузочная \\
- максимальная \\
- расчетная & 35 & - \\
\hline Крейсерская скорость, & 20 & 20 \\
км/час & \multicolumn{2}{|c|}{750} \\
\hline Крейсерская высота, км & \multicolumn{2}{|c|}{$9,45-12,0$} \\
\hline Практическая дальность & \multicolumn{2}{|c|}{} \\
с грузом, км: & 3000 & - \\
- 47 т & 5100 & - \\
- 35 т & 6600 & 3000 \\
- 20 т & \multicolumn{2}{|c|}{150} \\
\hline Топливная эффективность, \\
г/т-км
\end{tabular}

\section{2. Преемственность конструкции отечественных} средних оперативно-тактических военно-транспортных самолетов с ТВВД и ТРДД

\section{Основные задачи}

- перевозка личного состава, техники, грузов и средств материально-технического обеспечения между стратегическими направлениями;

- доставка воинских формирований, техники и грузов в интересах проведения контртеррористических, миротворческих и логистических операций;

- доставка частей и соединений десантно-штурмовых войск и сухопутных войск в районы боевого предназначения;

- обеспечение перебазирования авиационных частей и соединений.

\section{Аэродинамическая компоновка самолета}

Самолет представляет собой высокоплан с крылом умеренной стреловидности,с герметичным фюзеляжем, палубным хвостовым оперением и шасси трехопорной схемы, четырьмя двигателями и вспомогательной силовой установкой.

Крыло относительно большого удлинения $(\lambda=9,5)$ имеет умеренно сверхкритический профиль П-208 и состоит из центроплана и двух стреловидных консолей трапециевидной формы в плане. На задней кромке крыла расположены две секции элеронов и шесть секций интерцепторов.

Фиксированное горизонтальное оперение установлено на фюзеляже. Руль высоты - двухзвенный с конструктивной осевой компенсацией.

Вертикальное оперение состоит из киля и двухзвенного трехсекционного руля направления.

Шасси рычажного типа состоит из одной стойки передней опоры и двух трехстоечных основных опор. Все стойки шасси убираются в ниши, расположенные в нижней части фюзеляжа и в обтекатель основных опор самолета.

\section{Общая компоновка фюзеляжа самолета}

Самолет скомпонован по традиционной схеме с верхним расположением крыла. От переднего шпангоута до гермостворки и гермощитков грузолюка занимает гермозона фюзеляжа. Ниши передней и основных и опор шасси - негерметичны. Фюзеляж двухпалубный.

В носовой части фюзеляжа размещаются:

- радиопрозрачный обтекатель, в котором размещаются антенны бортового радиоэлектронного оборудования, радиолокатор и оптико-электронная прицельная система;

- в верхней части - кабина экипажа, аварийноспасательное оборудование, бытовое оборудование и техотсек с радиооборудованием, фонарь с форточками и верхний аварийный люк, пол с крышкой люка для входа в кабину экипажа, в районе рабочего места штурмана установлен блистер;

- в нижней части расположен технический отсек, где установлена основная часть электронного оборудования, стационарный туалет с системой водоснабжения и рециркуляционной системой удаления отходов, рабочее место техника по десантному оборудованию, входная лестница в кабину экипажа совмещенная с шахтой аварийного покидания.

В средней части фюзеляжа имеется входные двери, аварийные люки, грузовой пол, центроплан крыла, ниша стоек основного шасси, обтекатель стоек основного шасси, отсек ВСУ.

В хвостовой части фюзеляжа имеется грузовой люк, и отсек крепления хвостового оперения и законцовка фюзеляжа. 

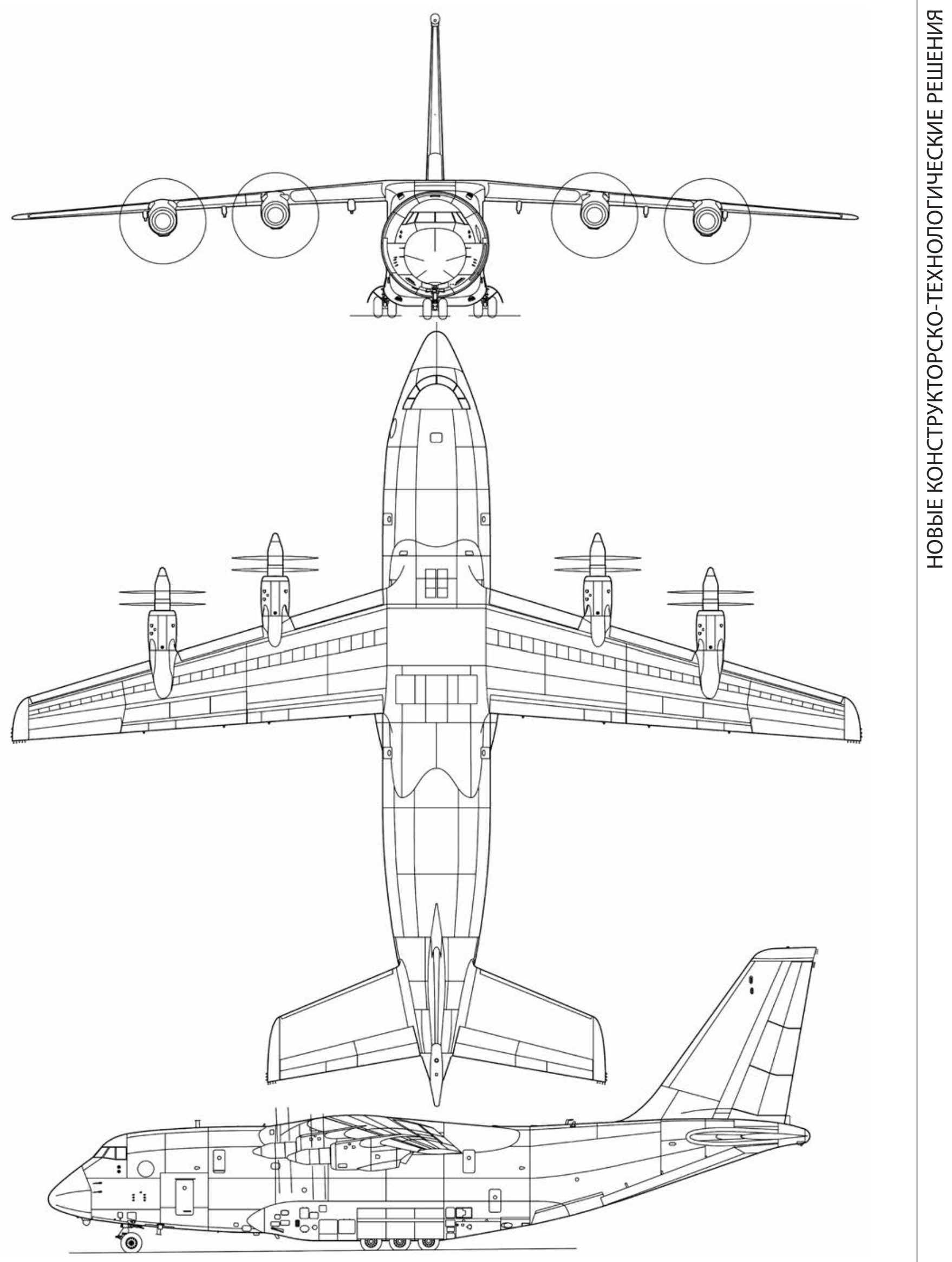

Рис. 2. Общий вид самолета с ТВД 


\section{Конструкция планера}

Фюзеляж. Фюзеляж самолета представляет собой цельнометаллический полумонокок с продольным набором из стрингеров и балок, поперечным набором из шпангоутов и работающей обшивкой с усилениями в зонах вырезов под проемы люков, дверей, остекления и оборудование самолета. Поперечное сечение мидельной части фюзеляжа окружность.

Фюзеляж условно разделен по длине на носовую, среднюю и хвостовую части.

В носовой части фюзеляжа имеется носовой обтекатель, а в хвостовой части - законцовка с хвостовым обтекателем. В носовой части фюзеляжа расположена кабина экипажа, которая отделена перегородкой (по шпангоуту) от грузовой кабины. В передней части кабины экипажа расположен фонарь с форточками, в верхней части кабины имеется аварийный люк. Вход в кабину экипажа осуществляется из грузовой кабины по лестнице через люк в полу кабины экипажа. Под полом кабины экипажа расположен технический отсек, в котором имеются ниша передней опоры шасси, закрываемая снаружи створками, и шахта аварийного выхода экипажа для покидания самолета в воздухе с нижним аварийным люком, открываемым наружу самолета.

Остекление фонаря кабины экипажа состоит из передних лобовых, боковых стекол и стекол двух форточек и обеспечивает достаточный обзор пилотам в полете. Лобовые стекла электрообогреваемые и их крепление выдерживает нормируемый удар птицы.

В средней и частично в носовой и в хвостовой частях фюзеляжа расположена грузовая кабина, в которой имеется грузовой пол, состоящий из силового настила с шестью рядами рельсов с пазом и семью рядами гнезд под швартовочные узлы. В настиле пола имеются два люка для доступа в подпольные пространства.

На самолете предусмотрена установка второй палубы, с помощью восьми секций и трапов для подхода к верхним аварийным люкам.

В передней части грузовой кабины, на левом и правом бортах, имеются две боковые двери. Для входа в самолет и выхода из него используется левая дверь с бортовым трапом, убираемым вручную и устанавливаемым на борту внутри фюзеляжа. Двери открываются наружу в направлении полета как вручную, так и дистанционно.

В грузовой кабине отечественного среднего оперативно-тактического военно-транспортного самолета с ТВВД расположены два нижних и четыре верхних боковых аварийных люка, открываемых вручную наружу самолета.

В грузовой кабине отечественного среднего оперативно-тактического военно-транспортного самолета с ТРДД расположены четыре верхних боковых аварийных люка и четыре двери, две из которых введенные дополнительно в нижнюю часть конструкции фюзеляжа в конце средней части Ф-2 вместо двух аварийных люков для обеспечения десантирования личного состава.

Окна, расположенные на боковых дверях, всех боковых аварийных люках и на обоих бортах фюзеляжа, обеспечивают освещение дневным светом и обзор из грузовой кабины. Также имеются окна осмотра стабилизатора, размещенные в грузовой кабины и подсвета, размещенные вне гермозоны. На потолке вдоль кабины установлены два монорельса для электротельферов.

В хвостовой части фюзеляжа расположен грузовой люк, состоящий из рампы с четырьмя трапами, гермостворки и двух гермощитков, ограничивающих гермозону фюзеляжа, а также средней и хвостовой створки двух боковых створок.

В зоне стыковки фюзеляжа и крыла расположен зализ с эксплуатационными люками и съемными панелями для доступа к оборудованию, размещенному внутри зализа.

На обоих бортах фюзеляжа расположен обтекатель основных опор шасси, имеющий створки в зоне ниши основных опор шасси и люки для обслуживания агрегатов и оборудования систем самолета, а также навесные крышки для доступа в отсек ВСУ.

В конструкции всех наружных боковых дверей и аварийных люков, рампы, гермостворки и гермощитков и створок грузового люка предусмотрены средства для исключения их самопроизвольного открытия в полете, а также заклинивания дверей и люков в случае аварийной посадки или разрушения их при приводнении самолета. Устройства открытия боковых дверей и аварийных люков, служащих аварийными выходами, выполнены простыми, имеют маркировку о способе их открытия и не требуют приложения чрезмерных усилий для открытия их вручную.

На фюзеляже обеспечена защита конструкции от коррозии для снижения или потери прочности при воздействии окружающей среды во всех ожидаемых условиях эксплуатации, а также имеются вентиляция и дренаж во всех его отсеках, зализе крыла и обтекателе основных опор шасси. На фюзеляже обеспечена защита конструкции от пожара в зоне установки ВСУ.

Имеется усиление бортов фюзеляжав зоне вращения винтовентиляторов МДУ.

Крыло. Крыло самолета состоит из центроплана, левой и правой консольных частей.Кессоны крыла, центроплана и консолей крыла - двухлонжеронной конструкции, выполнен из высокопрочного алюминиевого сплава. Схема полукрыла указана на рис. 3.

Onерение. Оперение самолета выполнено свободнонесущим, нормальной палубной схемы с одним центрально расположенным килем. 
Стабилизатор состоит из: кессона, носовой, хвостовой частей и законцовки.

Киль состоит из кессонной, носовой, хвостовой частей и законцовки.

Грузовая кабина. Для размещения доставляемых грузов и личного состава на самолете имеется грузовая кабина (рис. 4). Грузовая кабина имеет следующие габариты:

$\begin{array}{ll}\text { Длина } & 22,6 \mathrm{~m} \\ \text { Длина без рампы } & 18,7 \mathrm{~m} \\ \text { Ширина (по полу) } & 4,0 \mathrm{~m} \\ \text { Ширина максимальная } & 4,9 \mathrm{~m} \\ \text { Ширина на высоте } 3,85 \mathrm{~m} & 2,9 \mathrm{~m} \\ \text { Высота за центропланом } & 4,185 \mathrm{~m} \\ \text { Высота под центропланом } & 4,1 \mathrm{~m} \\ \text { Объем } & 370 \mathrm{~m}^{3}\end{array}$

По левому и правому борту имеются по 4 иллюминатора, обеспечивающие возможность выполнения в грузовой кабине работ по швартовке грузов при закрытом грузолюке и дневном освещении, а при выполнении швартовки в ночное время подсветка выполняется светильниками, размещенными в нижних коробах СКВ.

Грузовой пол. Грузовой пол при транспортировке техники и грузов выдерживает следующие нагрузки:

- в любом месте грузового пола может транспортироваться техника с давлением в колесах до 0,54 МПа (5,5 кгс/см²);

- в любом месте грузового пола может транспортироваться груз «навалом», создающий нагрузку 0,45 МПа (4,6 кг $\left./ \mathrm{cm}^{2}\right)$.

Вспомогательная силовая установка (ВСУ). В состав ВСУ входит один вспомогательный двигатель размещенный в левом обтекателе основного шасси.

Шасси. Самолет оборудован трехопорным убирающимся шасси, которое состоит из двух основных и передней опоры с управляемыми колесами (рис. 5, а-б).

Параметры колес, тормозов и шин обеспечивают безопасную эксплуатацию самолета.
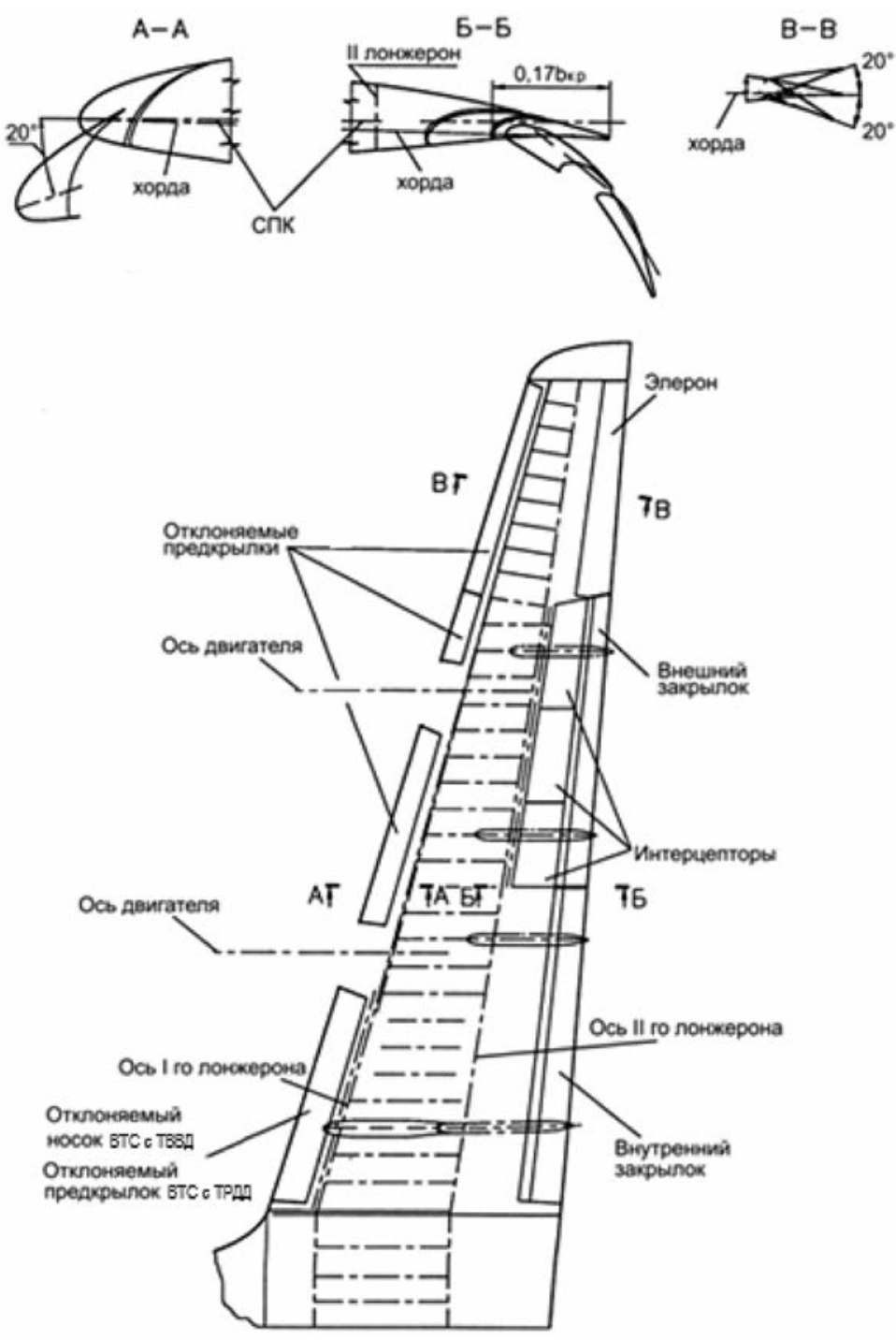

Рис. 3. Схема крыла

\section{3. Задачи для совершенствования отечественного среднего оперативно-тактического военно-транспортного самолета с ТВВД}

1. Уменьшение шума на местности (поскольку обеспечивается только для Главы 3 Приложения 16 ИКАО).

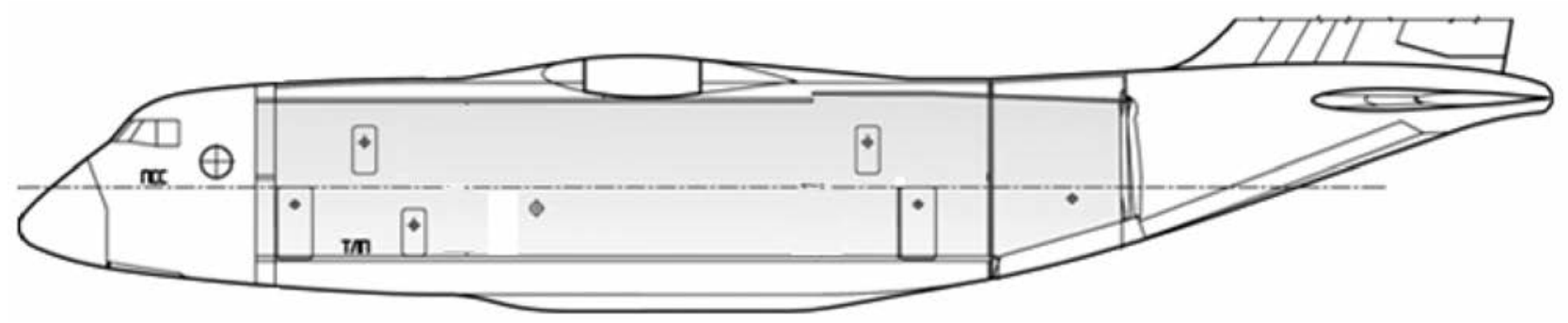

Рис. 4. Схема грузовой кабины 

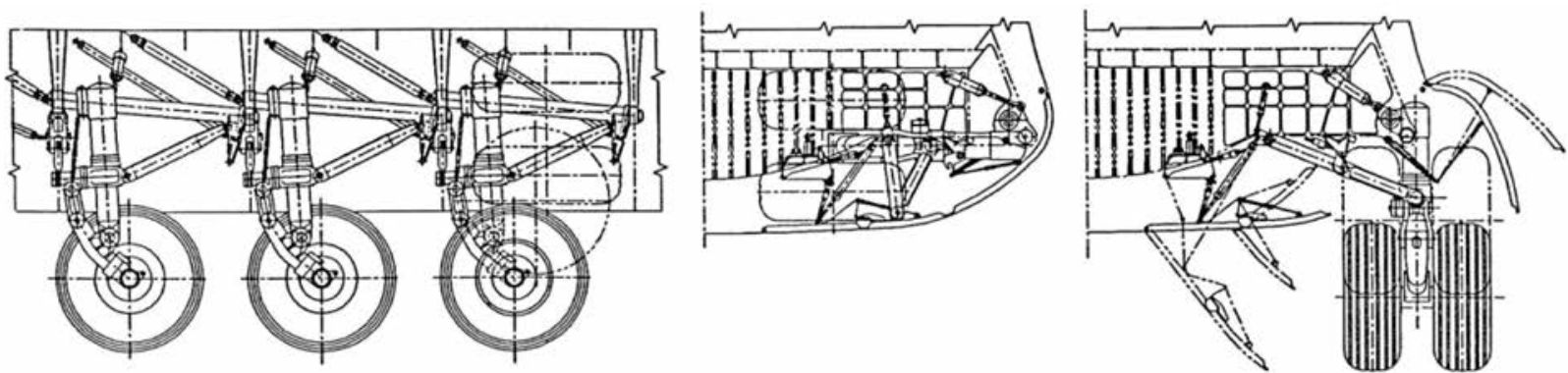

a)
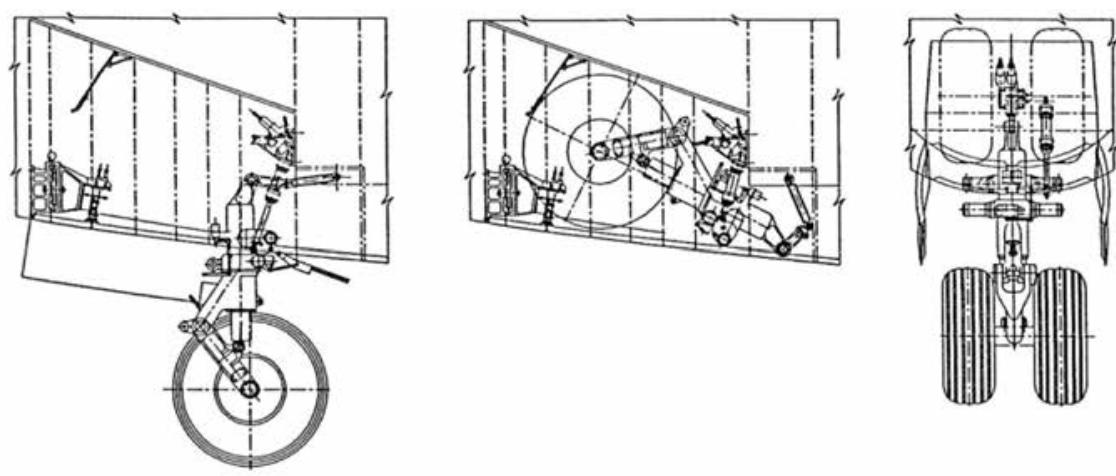

б)

Рис. 5. Схема шасси: $a$ ) основной опоры; б) передней опоры

2. Снижение потерь полного давления на входе в двигатель.

3. Уменьшение времени на обслуживание.

4. Уменьшение потребляемой электрической мощности на самолете.

5. Расширение возможностей по отбору воздуха от компрессора двигателя.

6. Обеспечение величины угла наклона рампы и подтрапников в положении для погрузки (выгрузки) техники $-12^{\circ}$.

7. Установка дверей для десантирования личного состава в хвостовой части самолета по стандартам НАТО.

\section{4. Совершенствование отечественного среднего оперативно-тактического военно-транспортного самолета с ТВВД}

Для устранения недостатков предполагается:

I. Установка на пилоны под крылом четырех турбореактивных двухконтурных двигателей CFM Leap производства CFM International (рис. 6) с обеспечением обдувки закрылков.

Выбор новых маршевых двигателей произведен исходя из максимально-возможной идентичности их весовых и тяговых характеристик с исходной силовой установкой, сохранения комплекса летнотехнических характеристик, включая параметры

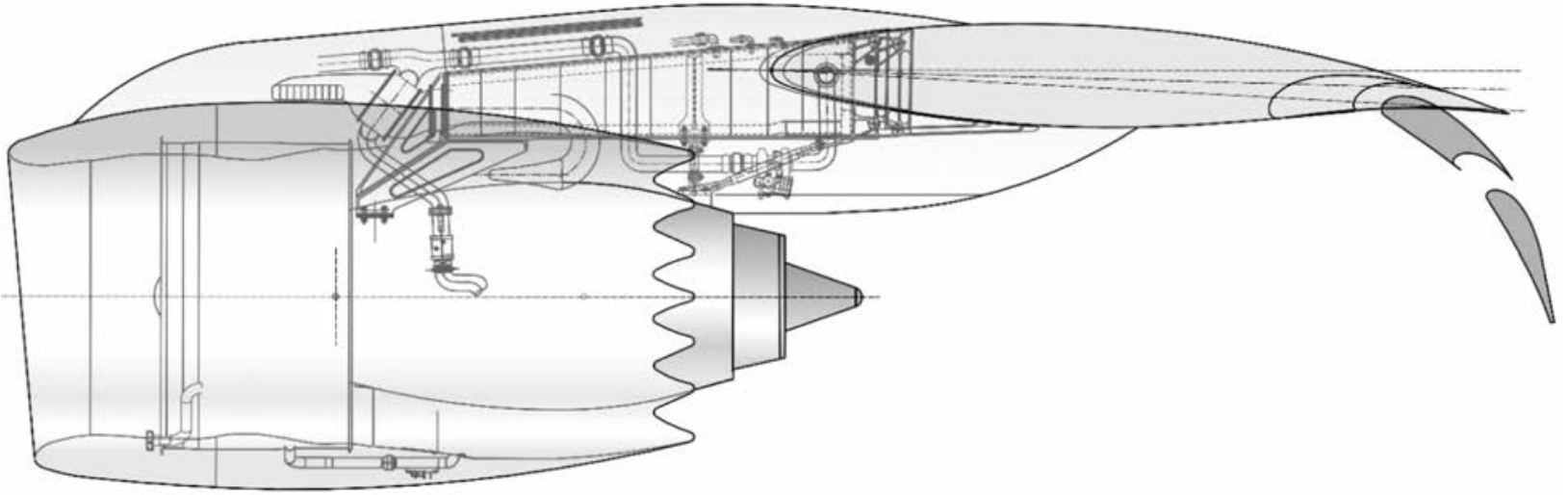

Рис. 6. Силовая установка 
КВП, не ниже, чем у самолета с ТВВД, a также обеспечения флаттерных характеристик при больших скоростях полета.

Замена маршевой силовой установки дает следующие преимущества:

- возможность обеспечения шума на местности по IV главе ICAO;

- повышенный комфорт экипажу в грузовой кабине - шум менее 80 дБА;

- возможность повышения ресурса планера и систем за счет снижения вибрационных и акустических нагрузок;

- возможность получения большего количества отбираемого воздуха для нужд обогрева поверхностей крыла и оперения;

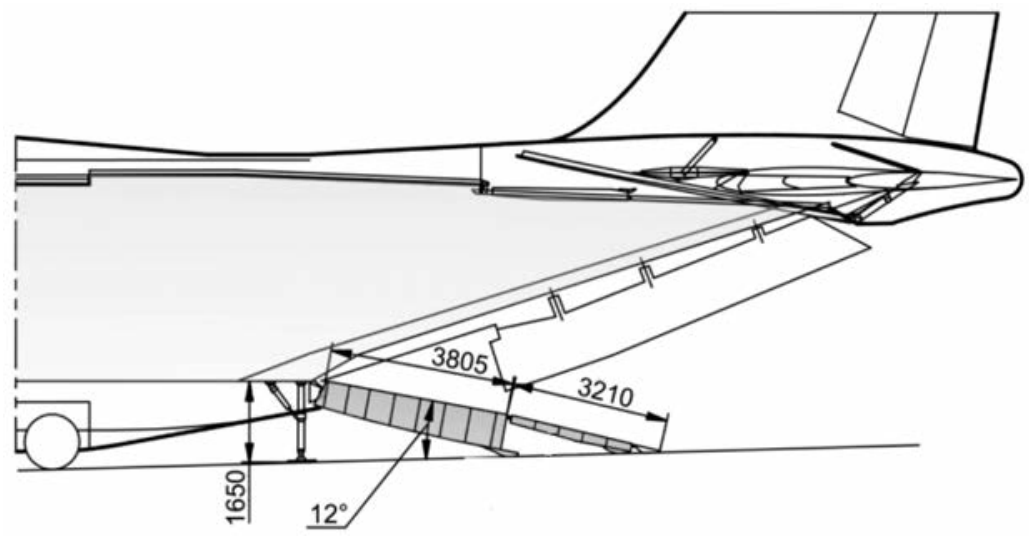

- возможность уменьшения радиолокационной заметности;

- возможность повышения производительности полетов на $7-10 \%$;

- возможность повышения технической готовности самолета за счет меньшей трудоемкости ТОиР. качества за счет отсутствия обдувки и уменьшения $S_{\text {мид }}$ мотогондолы;

- возможность получения более приемлемых центровок самолета;

- трудоемкость ТОиР МДУ м систем на 30-35\%

Рис. 7. Схема угла наклона рампы

II. Для обеспечения угла наклона рампы и подтрапников в положении для погрузки (выгрузки) техники $-12^{\circ}$ (рис. 7) предполагается усовершенствовать систему регулирования высоты грузового пола (РВГП).

РВГП предназначена для уменьшения высоты грузового пола при проведении погрузочно-разгрузочных работ, а также для улучшения условий при наземном обслуживании.

Усовершенствование РВГП состоит в обеспечении самолета системой увеличения высоты передней опоры шасси и системой приседания основных опор шасси, для опускания хвостовой части фюзеляжа до уровня, требующегося при погрузочных операциях (рис. 8).
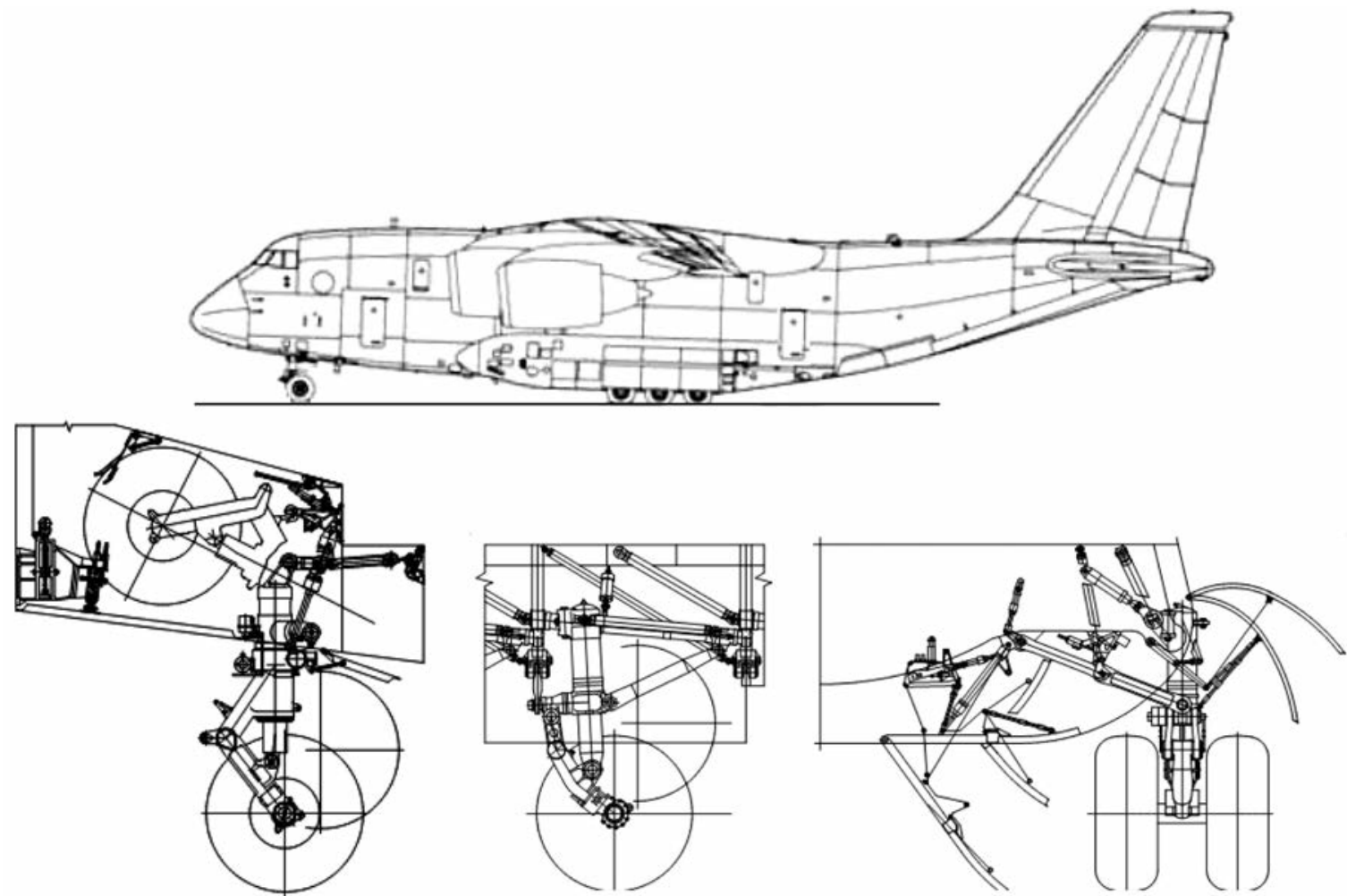

Рис. 8. Самолет с присевшими основными стойками шасси и приподнятой основной стойкой шасси 
III. Для обеспечения десантирования личного состава с парашютами типа Т-10, Т-11 в соответствии с требованиями НАТО на самолете в нижнюю часть конструкции фюзеляжа в конце средней части Ф-2 вместо левого и правого аварийных люков вводятся двери для десантирования (рис. 4).

5. Основные характеристики отечественного среднего военно-транспортного самолета с ТРДД (табл. 2)

Таблица 2

Основные летно-технические характеристики отечественного среднего оперативно-тактического военно-транспортного самолета с ТРДД (рис. 9)

\begin{tabular}{|c|c|c|}
\hline Режим применения & $\begin{array}{c}\text { Режим } \\
\text { ОВП }\end{array}$ & $\begin{array}{c}\text { Режим } \\
\text { КВП }\end{array}$ \\
\hline Потребная длина ВПП, м & 1900 & $600-800$ \\
\hline Взлетная масса, т & 145 & 118 \\
\hline $\begin{array}{l}\text { Грузоподъемность, т: } \\
\text { - перегрузочная } \\
\text { - максимальная } \\
\text { - расчетная }\end{array}$ & $\begin{array}{l}47 \\
35 \\
20\end{array}$ & $\begin{array}{l}- \\
- \\
20\end{array}$ \\
\hline $\begin{array}{l}\text { Крейсерская скорость, } \\
\text { км/час }\end{array}$ & \multicolumn{2}{|c|}{$750-800$} \\
\hline Крейсерская высота, км & \multicolumn{2}{|c|}{$9,45-12,0$} \\
\hline $\begin{array}{l}\text { Практическая дальность } \\
\text { с грузом, км: } \\
\text { - } 47 \text { т } \\
-35 \text { т } \\
\text { - } 20 \text { т } \\
\text { - без груза }\end{array}$ & $\begin{array}{l}2720 \\
4700 \\
6300 \\
7370\end{array}$ & $\begin{array}{c}- \\
- \\
3370\end{array}$ \\
\hline $\begin{array}{l}\text { Топливная эффективность, } \\
\text { г/т-км }\end{array}$ & \multicolumn{2}{|c|}{155} \\
\hline
\end{tabular}

\section{6. Преимущества отечественного среднего} оперативно-тактического военно-транспортного самолета с ТРДД над основными конкурентами

Отечественный средний оперативно-тактический военно-транспортный самолет с ТРДД является образцом авиатехники, уникальным с точки зрения своих технических и эксплуатационных характеристик.

Это единственный в мире самолет, обеспечивающий непосредственную доставку грузов и техники на короткие, длиной 600-800 м, слабоподготовленные грунтовые аэродромы с прочностью грунта до 6 кгс $/ \mathrm{cm}^{2}$. В режиме КВП обеспечивается перевозка 20 т грузов на 3370 км. Вместе с тем, в перегрузочном варианте применения, может перевозить 47 т грузов на дальность 2720 км, что позволяет ему выполнять задачи самолетов существенно большей размерности. По этим показателям он существенно превышает возможности аналогичного по назначению европейского самолета A400M, который может эксплуатироваться с аэродромов не короче 915 м и поднимать груз не более 37 тонн.

Самолет позволяет выполнять высокоточное десантирование военных грузов, включая моногрузы массой до 21 т, что превышает возможности самолетов семейства Ил-76 и европейского А400M и приближается к возможностям тяжелого военнотранспортного самолета C-17, имеющего вдвое большую взлетную массу и втрое большую стоимость.

По своим габаритам и взлетному весу средний оперативно-тактический военно-транспортный самолет с ТРДД приближается к европейскому самолету Airbus Military A400M, но по ряду основных летно-технических характеристик существенно превосходит его (табл. 3).

Таблица 3

Сравнение отечественного среднего оперативно-тактического военно-транспортного самолета с европейским самолетом Airbus Military A400M

\begin{tabular}{|l|c|c|c|}
\hline & ВТС с тРДД & A400M & Различие \\
\hline Объем грузовой кабины, ${ }^{3}$ & 370 & 356 & $4 \%$ \\
\hline Максимальная грузоподъемность, т & 47 & 37 & $27 \%$ \\
\hline Минимальная длина ВПП в режиме КВП & $600-800$ & 915 & $34-14 \%$ \\
\hline $\begin{array}{l}\text { Максимальная грузоподъемность в режиме КВП } \\
\text { (ВПП = 915 м), т }\end{array}$ & 35 & 20 & $42 \%$ \\
\hline $\begin{array}{l}\text { Дальность полета в режиме КВП (ВПП = 915 м) с гру- } \\
\text { зом 20 т, км }\end{array}$ & 4900 & 2000 & $59 \%$ \\
\hline Дальность полета с грузом 37 т, км & 4700 & 3700 & $22 \%$ \\
\hline
\end{tabular}




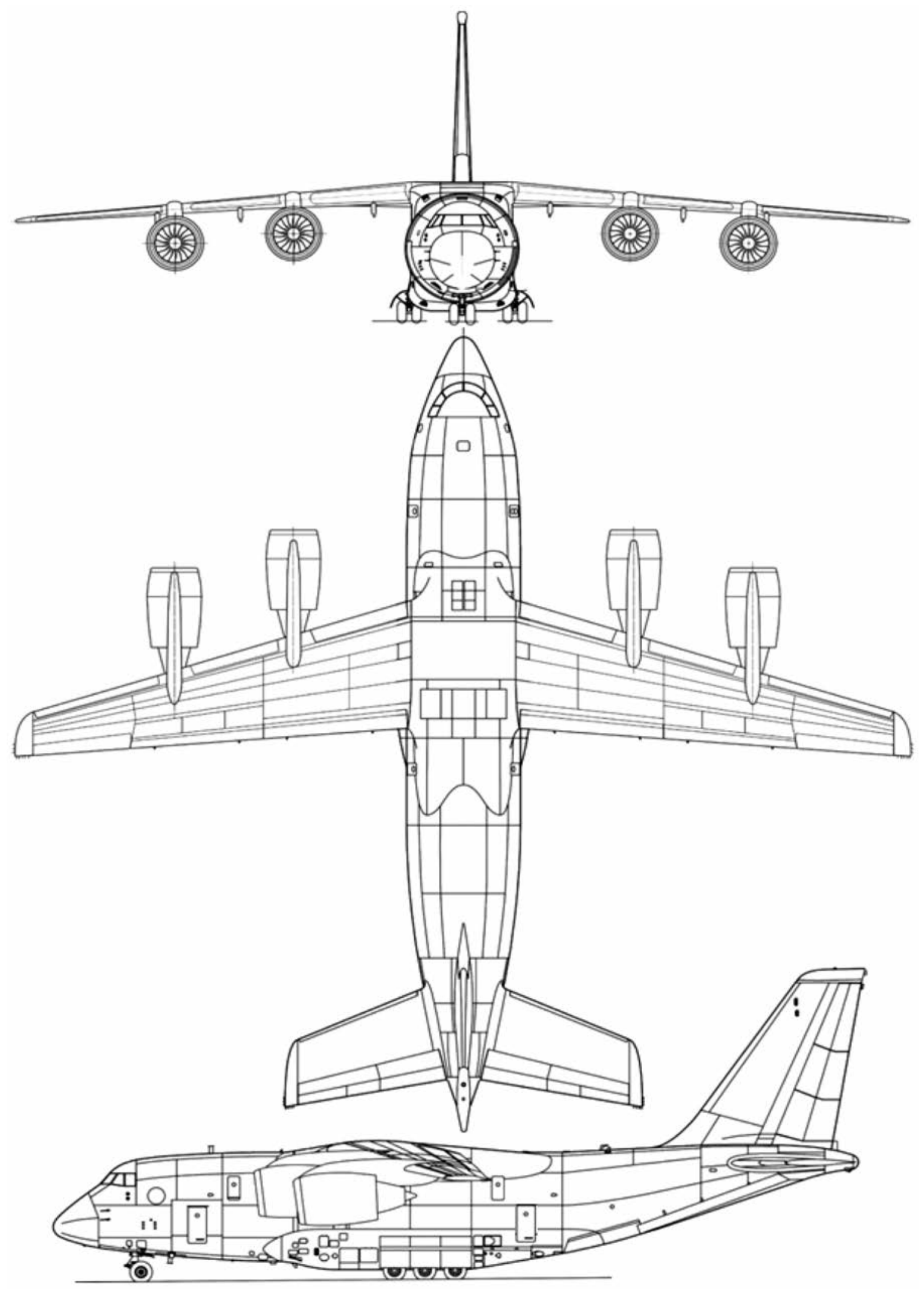

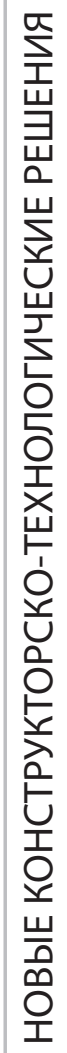

Рис. 9. Общий вид самолета с ТРдД 
Для достижения высокого технического уровня на самолете разработана уникальная аэродинамическая компоновка с высокомеханизированным крылом, которая позволяет получить очень высокую подъемную силу, необходимую для осуществления короткого взлета и посадки.

Весовое совершенство средний оперативно-тактический военно-транспортный самолет с ТРДД обеспечивается рациональной конструкцией и широким применением современных авиационных материалов, а в особенности - композиционных. Из композитов сделаны такие высоконагруженные элементы конструкции как вертикальное и горизонтальное оперение, механизация крыла, обтекатели крыла и шасси и створки грузолюка.

Кроме того, самолет может автономно базироваться на не подготовленных площадках без использования специальных аэродромных средств поддержки. Самолет оборудован комплектом погрузочного оборудования для обеспечения загрузки и выгрузки грузов вне базы, а также автономной бортовой системой технического обслуживания.

\section{7. Основные конструктивно-технологические \\ характеристики отечественного среднего} оперативно-тактического военно-транспортного самолета с ТРДД

На самолете с ТРДД обеспечена максимальная преемственность с самолетом с ТВВД. Самолет является высокопланом с крылом умеренной стрело- видности с герметическим фюзеляжем, палубным хвостовым оперением и шасси трехопорной схемы. Силовая установка имеет четыре турбореактивных двигателя.

Планер самолета состоит со следующих составных агрегатов:

- фюзеляж;

- крыло;

- хвостовое оперение;

- шасси.

Схема конструктивно-технологического членения отражена на рис. 10.

Каждый из агрегатов, в свою очередь, расчленён продольными и поперечными разъёмами и стыками на сборочные единицы - отсеки, секции, панели, узлы, которые могут изготавливаться независимо друг от друга, собираться раздельно в своих сборочных приспособлениях и подаваться на последующие этапы сборки в максимально законченном виде. Членение агрегатов планера позволяет выбирать необходимую степень укрупнения сборочных единиц, исходя из программы производства самолёта и экономически целесообразной транспортировки между предприятиями-изготовителями в случае кооперированного производства.

Конструктивно-технологической особенностью планера самолёта являются фланцевые плоские стыки фюзеляжа с крылом и оперением, центральной и консольных частей крыла. Это позволяет применить агрегатный принцип проектирования и производства агрегатов, максимально законченных

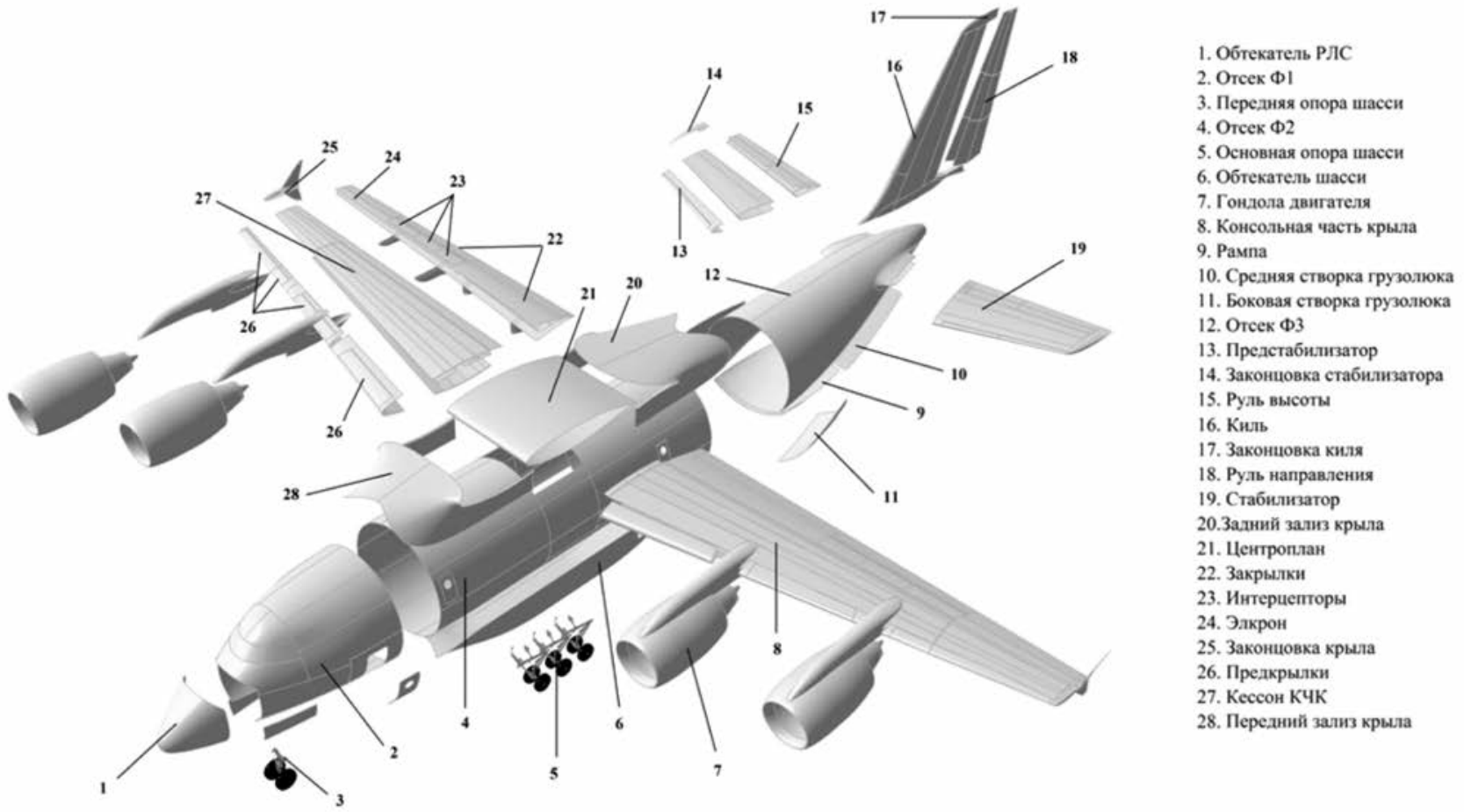

Рис. 10. Конструктивно-технологическое членение отечественного среднего оперативно-тактического военно-транспортного самолета 
по сборке, испытаниям и отработке систем в условиях кооперированного производства, а также сократить время и упростить процесс стыковки агрегатов при окончательной сборке самолёта.

Системы самолёта спроектированы в основном с учётом членения конструкции планера на агрегаты и отсеки (в том числе отсеки фюзеляжа Ф-1, Ф-2 и Ф-3), что обеспечивает возможность поставлять их на окончательную сборку самолёта максимально законченными, как по сборке, так и по монтажу систем.

Фюзеляж является цельным металлическим полумонококом с грузовым полом. Продольный силовой набор фюзеляжу состоит со стрингеров та балок, поперечного силового набора - из шпангоутов и перегородок. Членение фюзеляжа на отсеки:

- носовой (Ф-1);

- средний (Ф-2);

- хвостовой (Ф-3).

Между собой отсеки стыкуются различными стыками. Каждый с отсеков может независимо собираться в своих складальных стапелях. Герметическая зона фюзеляжу размещена между шпангоутами (шп.) 2 та 57.

Материал обшивок и типовых шпангоутов листовые заготовки толщиною $1,2 \ldots 2$ мм из алюминиевого сплава 1163АМВ, материал силовых боковых шпангоутов и фитингов - алюминиевый сплав типа 1933ТЗ, материал балок и профилей - алюминиевые сплавы типа Д16чТ, В95.

Типовые шпангоуты Z-образного сечения, гнутые из листа с просечками под стрингера, сборныеиз прессованных профилей та стенок.

В конструкции фюзеляжа используются соединения:

- обшивок со стрингерами шпангоутами - клепка высоко ресурсными заклепками;

- продольные и поперечные стыки панелей клепка на клей типа ВК-9 под слоем ВК-25;

- подкладные листы под окантовки дверей та люков устанавливается на клей типа ВК-51А;

- в высоконагруженных стыках используются болты и болт-заклепки из титанового сплава с упругопластическим натягом.

Герметизация соединений фюзеляжа обеспечивается проходными швами за счет герметика та клея в середине шва, непроходными швами - за счет высоко ресурсного герметического крепления.

В конструкции планера и систем самолета используются материалы и полуфабрикаты, освоенные в металлургической промышленности и широко употребляемые на многих современных самолетах, в том числе сертифицированных.

Крыло. Крыло самолета имеет трапециевидную форму и состоит с центральной части крыла (ЦЧК), левой и правой консольных частей (КЧК). На передней кромке каждого полукрыла установ- лены предкрылки. На задней кромке установлены элероны, двухсекционные закрылки и секционные интерцепторы.

Центральная часть крыла. Центральная часть крыла кессонного типа, двухлонжеронная, заполняется топливом. Продольный силовой набор состоит из лонжеронов и монолитных панелей. Поперечный набор состоит из семи нервюр - 0-3 прав./лев.

I и II лонжероны - сборно-монолитной конструкции. Состоят из верхней (алюминиевый сплав типа 1973Т2), нижней (алюминиевый сплав типа 1161 T) прессованных балок уголкового сечения и монолитных кронштейнов стыка со средней частью крыла (алюминиевый сплав типа 1933Т3).

С наружной стороны I и II лонжеронов установлены дуги для крепления ЦЧК с секциями панелей фюзеляжа. Материал дуг - алюминиевый сплав типа 1933 Т3.

Панели ЦЧК монолитные, с двумя законцовками, вафельной конструкции из прессованных плит. Верхние панели (4 шт.) из алюминиевого сплава типа 1973Т2, нижние панели (5 шт.) из алюминиевого сплава типа $1161 \mathrm{~T}$. Изготавливаются на станках с ЧПУ.

Нервюры сложно-клепанной конструкции, состоят со стенок, верхнего и нижнего поясов, стоек, продольных профилей и кронштейнов в стыке с дугой. В соединениях нервюр с ребрами панелей и стойками лонжеронов для компенсации погрешностей применяется полимерный заполнитель типа В3-27M. Все соединения имеющие проходные швы, герметизируются внутришовным герметиком типа У30MEC-5М.

Продольные стыки верхних и нижних панелей устанавливаются на болтах с упругопластическим натяжением. Стык ЦЧК с фюзеляжем - фланцевый, с общей обработкой отверстий $\varnothing 30 \mathrm{H7}-$ $\varnothing 42 \mathrm{H} 7$, сквозь прокладку $S=10$ мм и установкой болтов с натягом (рис. 11).

Верхние панели носовой части КЧК (4-12 н.К., 15-27 н.к.) изготовлены вакуум-автоклавным формованием из полимерных композиционных материалов (ПКМ) и посредством профиля крепятся к верхней панели кессона КЧК.

Консольная часть крыла. КЧК состоит из кессонной части, носовой и хвостовой частей.

Продольный силовой набор состоит из лонжеронов сборно-монолитной конструкции и монолитных панелей. Поперечный набор выполнен из 34 нервюр.

Нижние панели носовой части КЧК - съемные, изготовлены из ПКМ и крепятся к каркасу замками.

Хвостовая часть (4-16 н.к.) состоит из верхней панели сотовой конструкции, регулируемых подкосов и съемных нижних панелей, закрепленных нерегулируемыми подкосами и замками. 


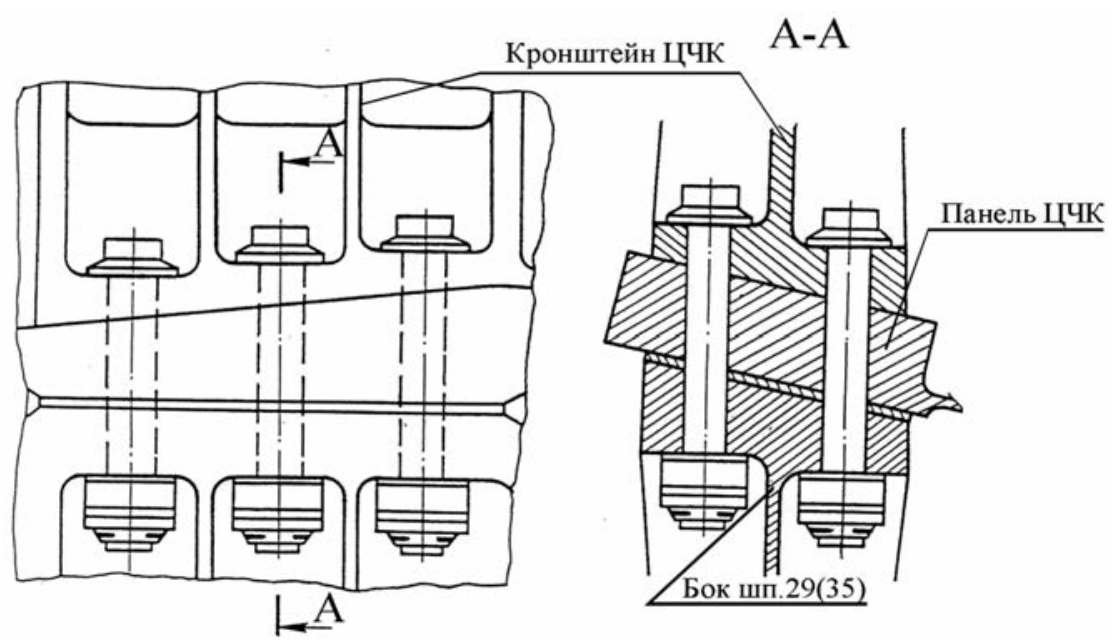

Рис. 11. Стык ЦЧК с фюзеляжем

Хвостовая часть (16-27 н.к.) состоит из верхней панели из ПКМ, подкладных лент, компенсаторов, накладок и съемных нижних панелей из ПКМ сотовой конструкции, закрепленных нерегулируемыми подкосами и замками.

В нижней части крыла для доступа в кессон реализованы люки лазы.

Защитное покрытие деталей из алюминиевых сплавов - сернокислое анодирование.

Законцовка крыла выполнена из ПКМ и состоит из обшивки, торцевой нервюры, узлов навески. Детали из ПКМ изготавливаются вакуум-автоклавным формованием. Сборка законцовки выполняется в стапеле.
Стык ЦЧК и КЧК отображен на рис. 12.

Агрегаты и узль механизации крыла. Передняя и задняя механизация КЧК включает:

- секции 1, 2, 3, 4 предкрылков;

- секции 1, 2 закрылков с механизмами в обтекателях;

- элерон;

- секции 1, 2, 3 интерцепторов.

Силовая установка. Маршевые двигатели крепятся к пилонам, которые состыковуются с лонжероном крыла на тех же узлах навески, что и балки двигателя ТВВД (рис. 13).

Балка крепления двигателя (3500×700×600 мм) состоит из верхней и нижней монолитных панелей

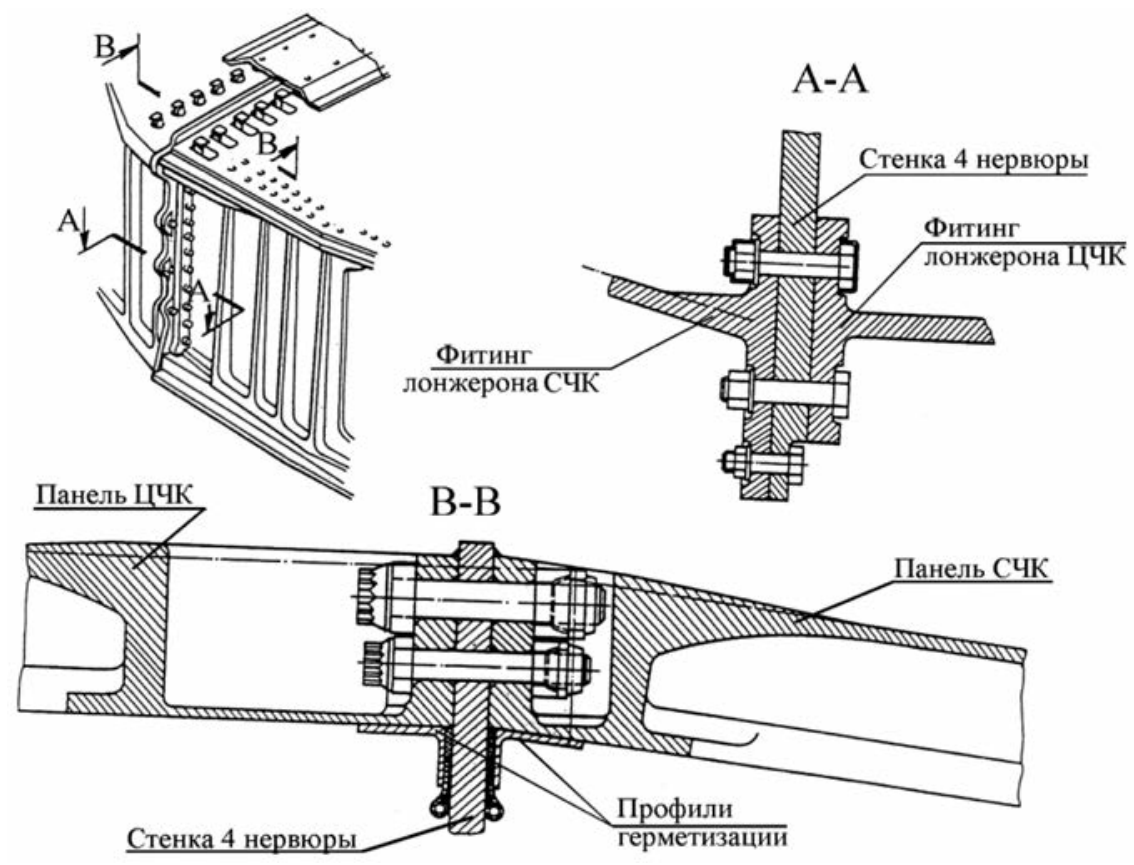

Рис. 12. Стык ЦЧК и КЧК (габариты 2800×850×350 мм) 


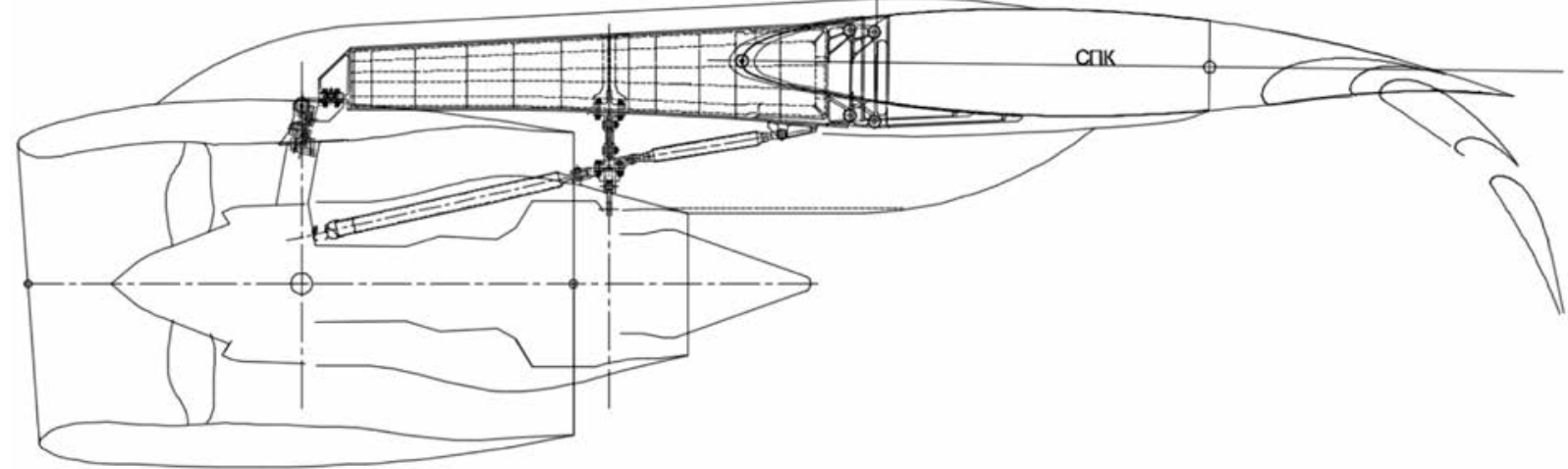

Рис. 13. Крепления пилона двигателя к лонжерону крыла

(материал типа 1973Т2), монолитных лонжеронов и нервюр (материал типа 1933Т3), изготовленных на станках с ЧПУ.

Гондола двигателя состоит из воздухозаборника, капота вентиляторного контура, обтекателя реверсивного контура, сопла вентиляторного контура и капота газогенератора.

Носок воздухозаборника металлический с противообледенительной системой (ПОС), крышки воздухозаборника из стеклопластика, панели капота газогенератора, обтекателя реверсивного контура, передней и средней частей сопла вентиляторного контура выполнены из стеклопластика трёхслойной конструкции с трубчатым заполнителем. Детали из стеклопластика изготавливаются вакуум-автоклавным формованием.

Шасси. В конструкции шасси применены детали из высокопрочных сталей и титановых сплавов. Детали фюзеляжа, крыла, оперения, шасси, работающие в условиях повышенного знакопеременного нагружения, подвергаются общему поверхностному упрочнению дробеструйным и вибрационным методами. На отдельных элементах деталей применено местное упрочнение (пневмодинамическое, обкатка, раскатка, обжатие, алмазное выглаживание).

В целях повышения износостойкости на отдельных поверхностях деталей шасси и гидравлической системы применено ионно-плазменное и плазменное напыление нитрида титана.

Бортовые системы самолета. Основными особенностями бортовых систем самолёта являются:

- широкое использование в воздушных системах высокоресурсного тонкостенного титанового трубопровода диаметром до 100 мм;

- применение высокопрочных сталей и титановых сплавов для изготовления деталей системы управления предкрылками (валы, шестерни, детали механизмов предкрылков и закрылков, шасси).

- использование унифицированного оборудования, применяемого на других типах самолетов отечественной разработки.
В конструкции планера широко используются высокопрочные алюминиевые сплавы типа 1933Т3, 1163, В95ПЧ, 1161, 1973Т2, Д16ЧТ.

Основные применяемые материаль. В конструкции планера и систем самолета используются материалы и полуфабрикаты, освоенные в металлургической промышленности и широко применяемые на многих современных самолетах, в том числе сертифицированных.

Детали, которые воспринимают высокие сосредоточенные нагрузки, изготавливаются из стали и титановых сплавов, в том числе:

- поковки и штамповки из стали типа 30ХГСН2МА-ВД для деталей шасси;

- поковки и штамповки из стали типа ВНС-5Ш для изготовления узлов навески двигателей и пилонов;

- поковки и штамповки из титанового сплава типа ВТ22 - для деталей шасси и механизации крыла;

- прутки из сталей типа ВНС-5Ш, 40ХН2МА-ВД, 30ХГСА, 07Х16Н6-Ш и титанового сплава ВТ16 для изготовления болтов.

В местах с высокими рабочими температурами и в агрессивной среде применяются коррозионностойкие стали типа 12Х18Н10Т, Х18Н9БЛ и титановые сплавы типа BT1-0 и ОТ4-1. Для изготовления трубопроводов применяется сталь типа 12Х18Н10Т и титановые сплавы типа ВТ1-0 и Пт7М.

Из неметаллических материалов в конструкции самолета используются:

- органическое и силикатное стекло - для остекления кабины экипажа;

- резины различных типов - в зависимости от назначения и условий эксплуатации;

- герметики типа У30МЕС-5м и ВИТЕФ-1 для герметизации топливных и воздушных отсеков.

Для защиты внутренней поверхности от коррозии предусмотрена обработка профилактическими составами Динитрол или НГ-222.

Для изготовления деталей и узлов из композиционных материалов используются: 
T-60;

- стеклоткани типа Т-10-80, T-10-14, Т-15(П) и

- ткани комбинированные Т-42\1-76;

- ткани технические СВМ арм. 56313;

- полимерсотопласты ПСП-1;

- углеленты типа ЕЛУР-П, УОЛ-ЗОО и ткани УТ-900;

- модифицированные эпоксидные связующие ЭДТ-69H;

- пленочные клеи ВК-41, ВК-36, ВКВ-46, ВКВ-3;

- жидкие клеи ВК-9, ВК-27, ВКВ-9, ВК-25;

- фенолформальдегидное соединение ФП-520;

- полиамидное связующее модифицированное СП-97.

Предусматривается использование зарубежных аналогов согласно утвержденному перечню возможных замен традиционно применяемых материалов (алюминиевые сплавы, металлические материалы из стали, титановые сплавы, металлические материалы с медных сплавов, неметаллические материалы, лакокрасочные материалы, ПКМ).

Основные конструктивно-технологические решения по планеру самолета обеспечивают следующую структуру применяемости конструкционных материалов, \%:

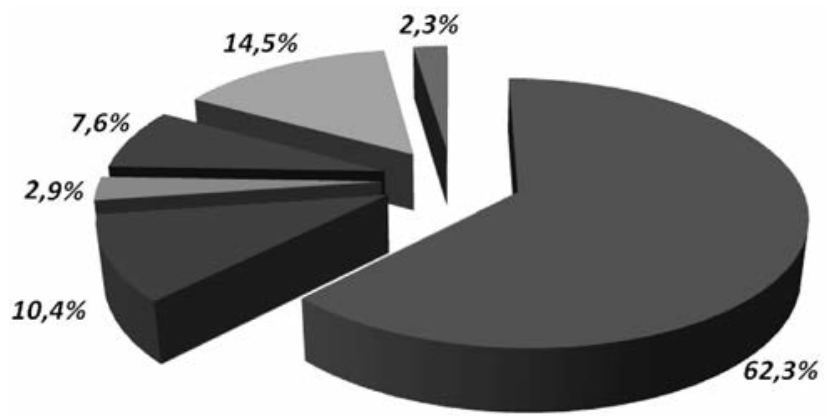

Алюминиевые сплавы и другие цветные металлы, $62,3 \%$ Конструкционные стали, $10,4 \%$

Нержавеющие и жаропрочные стали, $2,9 \%$

Титановые сплавы, 7,6\%

ПКМ и сотовые конструкции, $14,5 \%$

Неметаллы, 2,3\%

Рис. 14. Структура применяемости конструкционных материалов

Технологические проиессы производства. При изготовлении самолета необходимо использование всех видов производств, применяемых в современном самолетостроении. Рабочее проектирование самолета производится в тесном взаимодействии со специалистами технологических служб с целью высокой производственной технологичности за счет возможности использования современных высокопроизводительных технологий и инструмента.

При изготовлении деталей из листовых, профильных и трубчатых заготовок предполагается использование:
- формообразующего оборудования с ЧПУ;

- штамповочного оборудования с высоким удельным давлением.

В механообрабатывающем производстве предполагается применение современного оборудования с ЧПУ на различных операциях, в особенности при изготовлении силовых деталей планера, крупногабаритных и длинномерных деталей. Конструкция деталей позволяет применять методы высокоскоростной и высокопроизводительной обработки из рациональных металлургических заготовок и полуфабрикатов.

Детали фюзеляжа, крыла, оперения, шасси, работающие в условиях повышенного знакопеременного нагружения, подвергаются общему поверхностному упрочнению дробеструйным и вибрационным методами. На отдельных элементах деталей применено местное упрочнение (пневмодинамическое, обкатка, раскатка, обжатие, алмазное выглаживание).

В целях повышения износостойкости на отдельных поверхностях деталей шасси и гидравлической системы применено ионно-плазменное и плазменное напыление нитрида титана.

Конструкция сборочных единиц планера и их подсборок позволяет осуществлять их сборку в сборочных приспособлениях, как традиционного типа, так и в упрощенных приспособлениях нового типа с базированием по базовым отверстиям, которые специально предусматриваются в конструкции деталей (так называемая безстапельная сборка).

При выполнении разделки отверстий и постановки крепежных элементов предусмотрены необходимые подходы для выполнения операций специализированным ручным механизированным инструментом.

Для выполнения работ по изготовлению и монтажу бортовых электро и радиосистем широко применяется монтажный инструмент зарубежного производства.

При выполнении некоторых технологических процессов производства самолета необходимо проведение дополнительных процедур для обеспечения требуемого качества.

К таким процессам относятся:

- особо ответственные технологические процессы;

- специальные технологические процессы;

- новые технологические процессы.

Эти процессы должны выполняться в соответствии с действующими у изготовителя нормативными документами, разрабатываемыми согласно Авиационным правилам.

\section{8. Выводы}

1. Проанализированы особенности конструкции отечественного военно-транспортного самолета с 
ТВВД и преемственность использования достигнутых конструктивно-технологических особенностей при создании отечественного военно-транспортного самолета с ТРДД.

2. Внесены изменения в конструкцию отечественного военно-транспортного самолета связанные с установкой ТРДД и необходимостью достижения улучшенных характеристик.

3. Выполнен анализ достигнутых преимущественных характеристик отечественного военнотранспортного самолета с ТРДД в классе оперативно-тактических самолетов.

4. Отмечено существенное улучшение летнотехнических характеристик отечественного военно-транспортного самолета за счет улучшения характеристик воздухозаборника двигателя.

5. Выполнена оценка перераспределения отборов мощности от двигателя при установке ТРДД.

\section{Аббревиатуры}

ВПП - взлётно-посадочная полоса

ВСУ - вспомогательная силовая установка

ВТС - военно-транспортный самолет

ИКАО - Международная организация гражданской авиации, International Civil Aviation Organization (ICAO)

КВП - короткий взлет и посадка

КЧК - консольная часть крыла

МДУ - мото-двигательная установка

НАТО - Организация Североатлантического договора, Североатлантический Альянс, North Atlantic Treaty Organization

ОВП - общий взлет и посадка

ПКМ - полимерные композиционные материалы

ПОС - противообледенительная система

РВГП - система регулирования высоты грузового пола

СКВ - система кондиционирования воздуха

Ф-1 - носовой отсек фюзеляжа

Ф-2 - средний отсек фюзеляжа

Ф-3 - хвостовой отсек фюзеляжа

ТВВД - турбовинтовентиляторный двигатель

ТОиР - техническое обслуживание и ремонт

ТРДД - турбореактивный двухконтурный двигатель

ЦЧК - центральная часть крыла

\section{Сокращения}

н.к. - - нервюра крыла

Обозначения

$S \quad-$ толщина, мм

\section{Греческие символы}

$\lambda \quad-$ удлинение крыла

\section{Индексы}

мид - мидель

шп. - - шпангоут

\section{Литература}

[1] Гребенников, А. Г. Методология интегрированного проектирования и моделирования сборных самолетных конструкций [Текст]: монография/ А. Г. Гребенников.- Харьков: Нац. аэрокосм. ун-т «ХАИ», 2006. - $532 \mathrm{c}$.

[2] Кива, Д.С. Научные основы интегрированного проектирования самолетов транспортной категории [Текст]: монография/ Д. С. Кива, А. Г. Гребенников.- Харьков: Нац. аэрокосм. ун-т им. Н. Е. Жуковского «ХАИ», 2014.- Ч. 1. - 439 с.; - Ч. 3. - 376 с.

[3] Основы общего проектирования самолетов с газотурбинными двигателями [Текст]: монография/ П. В. Балабуев, С. А. Бычков, А. Г. Гребенников, В. Н. Желдоченко, А. А. Кобылянский, А. К. Мялица, В. И. Рябков, Т. П. Цепляева.- учеб. пособие. Ч. 1. - Харьков: «ХАИ», 2003. - 454 c.

[4] Проектирование систем силовых установок самолетов [Текст]: монография/ С. В. Епифанов, В. Д. Пехтерев, А. И. Рыженко, Р. Ю. Цуканов, В. Ф. Шмырев - учеб. пособие. - Харьков: «ХАИ», 2011. - 511 с. 
Bychkov S. A., Donets A. D., Shmyrev V. F.

ANTONOV, State-owned Enterprise. Ukraine, Kiev

\section{DEVELOPMENT OF THE CONCEPT OF NATIVE MIDDLE MILITARY TRANSPORT AIRPLANE WITH TURBOREACTIVE TWO-CIRCUIT ENGINES}

The features of the design and technological changes of the domestic military transport aircraft associated with the installation of CFM Leap turbojet dual-circuit engines instead of turbofan engines are considered.

Changes related to the improvement of the aircraft based on the results of ground and flight tests, taking into account NATO standards regarding the design of the airframe and aircraft systems, were noted and qualified.

The technological aspects of the organization of production of a domestic military transport aircraft with turbojet dual-circuit engines are considered.

The creation of a domestic medium military transport aircraft (An-188) with turbojet dual-circuit engines is made with the maximum use of the scientific and technical reserve accumulated during the creation of the domestic medium military transport aircraft with turbofan engines while maintaining the main structural, aerodynamic and strength characteristics, taking into account compliance with airworthiness requirements EASA CS-25, MIL-STD, STANAG. [dx.doi.org/10.29010/89.1]

Keywords: concept; medium operational tactical military transport aircraft; turbojet dual-circuit engine; turbofan engine; airframe and airplane systems design; structural, aerodynamic and strength characteristics; airworthiness requirements.

\section{References}

[1] Grebennikov, A. G. Metodologija integrirovannogo proektirovanija i modelirovanija sbornyh samoletnyh konstrukcij (2006). - Kharkov: Nac. ajerokosm. un-t «KhAI», 2006. - 532 p.

[2] Kiva, D. S. Nauchnye osnovy integrirovannogo proektirovanija samoletov transportnoj kategorii (2014) - Kharkov: Nac. ajerokosm. un-t «KhAI», 2014. - Ch. 1. - 439 p.; - Ch. 3. - 376 p.

[3] Osnovy obshhego proektirovanija samoletov s gazoturbinnymi dvigateljami (2003) P. V. Balabuev, S. A. Bychkov, A. G. Grebennikov, V. N. Zheldochenko, A. A. Kobyljanskij, A. K. Mjalica, V. I. Rjabkov, T. P. Cepljaeva. - ucheb. posobie. Ch. 1 - Kharkov: Nac. ajerokosm. un-t «KhAI», 2003. - 454 p.

[4] Proektirovanie sistem silovyh ustanovok samoletov (2011) S. V. Epifanov, V. D. Pehterev, A. I. Ryzhenko, R. Ju. Cukanov, V. F. Shmyrev - ucheb. posobie. - Kharkov: Nac. ajerokosm. un-t «KhAI», 2011. - 511 p. 